\title{
Feather mites (Acari, Astigmata) from Azorean passerines (Aves, Passeriformes): lower species richness compared to European mainland
}

\author{
Pedro Rodrigues ${ }^{1}$,*, Sergey Mironov ${ }^{2}$, Oldrich Sychra ${ }^{3}$, Roberto Resendes ${ }^{1}$, and Ivan Literak ${ }^{3}$ \\ ${ }^{1}$ CIBIO, Centro de Investigação em Biodiversidade e Recursos Genéticos, InBIO Laboratório Associado, Pólo dos Açores, \\ Universidade dos Açores, 9501-801 Ponta Delgada, Portugal \\ 2 Zoological Institute, Russian Academy of Sciences, 199034 Saint Petersburg, Russia \\ 3 Faculty of Veterinary Hygiene and Ecology, Department of Biology and Wildlife Diseases, University of Veterinary \\ and Pharmaceutical Sciences Brno, Palackeho 1-3, 61242 Brno, Czech Republic
}

Received 4 November 2014, Accepted 28 January 2015, Published online 11 February 2015

\begin{abstract}
Ten passerine species were examined on three islands of the Azores (North Atlantic) during 2013 and 2014 in order to identify their feather mite assemblages. We recorded 19 feather mite species belonging to four families of the superfamily Analgoidea (Analgidae, Proctophyllodidae, Psoroptoididae and Trouessartiidae). A high prevalence of feather mite species was recorded on the majority of the examined host species. Only three passerine species (Sylvia atricapilla, Regulus regulus and Serinus canaria) presented the same full complex of mite species as commonly occurs in the plumage of their closest relatives in continental Europe. Passer domesticus presented the same limited fauna of feather mites living in the plumage as do its co-specifics in continental Europe. Carduelis carduelis bears the same feather mite species as do most of its continental populations in Europe, but it lacks one mite species occurring on this host in Egypt. Turdus merula, Pyrrhula murina and Fringilla coelebs are missing several mite species common to their continental relatives. This diminution could be explained by the founder effect, whereby a limited number of colonizing individuals did not transport the full set of feather mite species, or by the extinction of some mite species after initially having reached the Azores. The only individual of Motacilla cinerea sampled in this study presented a new host record for the mite species Trouessartia jedliczkai.
\end{abstract}

Key words: Passeriformes, Feather mites, Host-parasite associations, Biodiversity, Prevalence, Azores.

\begin{abstract}
Résumé - Acariens plumicoles (Acari, Astigmata) de passereaux (Aves, Passeriformes) des Açores : richesse en espèces inférieure à celle du continent européen. Dix espèces de passereaux ont été examinées sur trois îles des Açores (Atlantique Nord) en 2013 et 2014 afin d'identifier leurs assemblages d'acariens plumicoles. Nous avons trouvé 19 espèces d'acariens plumicoles appartenant à quatre familles de la superfamille Analgoidea (Analgidae, Proctophyllodidae, Psoroptoididae et Trouessartiidae). Une prévalence élevée d'espèces d'acariens plumicoles a été trouvée sur la majorité des espèces hôtes examinés. Seules trois espèces de passereaux (Sylvia atricapilla, Regulus regulus et Serinus canaria) présentaient le même complexe complet d'espèces d'acariens qui existe généralement en Europe continentale dans le plumage de leurs parents les plus proches. Passer domesticus présentait la même faune limitée d'acariens plumicoles vivant dans le plumage que ses conspécifiques en Europe continentale. Carduelis carduelis hébergeait les mêmes espèces d'acariens plumicoles que la plupart de ses populations continentales en Europe, mais n'avait pas une espèce d'acarien qui vit sur cet hôte en Égypte. Turdus merula, Pyrrhula murina et Fringilla coelebs n'hébergeaient pas plusieurs espèces d'acariens communes à leurs parents continentaux. Cette diminution pourrait s'expliquer par l'effet fondateur, dans lequel un nombre restreint d'individus colonisateurs ne transportent pas l'ensemble des espèces de leurs acariens plumicoles, ou par l'extinction de certaines espèces d'acariens après avoir atteint les Açores. Le seul individu de Motacilla cinerea échantillonné dans cette étude a présenté une nouvelle mention d'hôte pour l'espèce d'acarien Trouessartia jedliczkai.
\end{abstract}

*Corresponding author: pedroreisrodrigues@yahoo.com

This is an Open Access article distributed under the terms of the Creative Commons Attribution License (http://creativecommons.org/licenses/by/4.0), which permits unrestricted use, distribution, and reproduction in any medium, provided the original work is properly cited. 


\section{Introduction}

Feather mites comprise a group of psoroptidian mites (Acariformes: Astigmata) with roughly 2600 currently accepted species arranged in 36-38 families and two superfamilies, Analgoidea and Pterolichoidea [16, 28, 30, 34, 36, 45]. These mites are parasites or commensals permanently living on birds, never leaving their hosts, and highly specialized to numerous and quite different microhabitats on the bird body $[7,16]$. Not all mites attributed to these superfamilies and named feather mites are true inhabitants of the plumage. While the majority of species indeed inhabit different types of plumage (flight feathers, body and down feathers), representatives of some families live in the internal cavities of the feather quill, on the surface of skin, in subcutaneous layers of the skin, and in the nasal cavities [7]. Feather mites are known from all extant orders of birds, including penguins (as recently determined), and species bear a complex of specific feather mite species living in different microhabitats on the host body [16, 29, 37].

Studies focusing on feather mite diversity have been conducted in most mainland countries of the European continent (see Mironov [26, 27] for major references). Such studies are lacking for the Atlantic islands and in particular for the archipelago of the Azores. This archipelago is situated towards the middle of the Atlantic Ocean. Its avifauna encompasses 40 breeding species, 14 of which are passerines and include the endemic Pyrrhula murina (Godman, 1866) and 7 other endemic subspecies [39]. To date, only two feather mite species have been reported from two procellariiform hosts from the Azores [48, 49]. In addition, the first study focusing upon arthropod ectoparasites associated with passerine birds on this archipelago was carried out only recently [21]. The study revealed that the assemblage on Sylvia atricapilla gularis (Alexander, 1898) is composed of common chewing louse species to this passerine in Europe and the prevalence of the parasites was much higher in the Azorean host population than in the mainland populations.

In the present paper, we report for the first time the presence of 19 feather mite species belonging to four families found on 10 different passerine hosts from three islands of the Azores. We also compare the feather mite complexes found on Azorean passerines with those known on these avian species or their closest relatives in continental Europe based on reference data, since host species that colonize new regions, such as isolated islands, often lose parasite species [11, 22, 52], but this assumption has never been tested on feather mites before.

\section{Materials and methods}

Our study was focused on three islands of the Azores archipelago, situated in the Atlantic Ocean between the latitudes $36^{\circ} 55^{\prime}$ and $39^{\circ} 43^{\prime}$ North and the longitudes $24^{\circ} 46^{\prime}$ and $31^{\circ} 16^{\prime}$ West: São Miguel $\left(37^{\circ} 48^{\prime} 35^{\prime \prime}\right.$ N $\left.25^{\circ} 12^{\prime} 51^{\prime \prime} \mathrm{W}\right)$, Santa Maria $\left(36^{\circ} 58^{\prime} 58^{\prime \prime} \mathrm{N} 25^{\circ} 05^{\prime} 27^{\prime \prime} \mathrm{W}\right)$ and Graciosa $\left(39^{\circ} 03^{\prime} 05^{\prime \prime} \mathrm{N} 28^{\circ} 00^{\prime} 51^{\prime \prime} \mathrm{W}\right)$. It is roughly $1500 \mathrm{~km}$ from continental Europe and $1900 \mathrm{~km}$ from continental North America.
The Azores encompass nine islands of recent volcanic origin (between 0.25 and $8 \mathrm{My}$ old) that are spread along a northwest-southeast line over more than $600 \mathrm{~km}$ [13].

A total of 253 passerines belonging to 10 of the 14 Passeriforme breeding species on the Azores (Table 1) were captured using mist nets within different habitats on the three islands of this study. Passerines were sampled at various locations on São Miguel during April, June and July 2013 and June 2014, and on Santa Maria and Graciosa during September 2013. Bird individuals were identified, ringed and immediately released into the wild after removing one primary remex and/or one rectrix feather sample containing feather mites as detected by the naked eye. The feathers removed were preserved in $96 \%$ ethanol for future processing. Under laboratory conditions, mite specimens were then mounted on microslides in Faure's medium according to a standard technique for small acariform mites [12]. Mites were identified by one of the authors (SM) using a Leica DM 5000B light microscope with differential interference contrast illumination. Specimens mounted on slides are deposited at the Zoological Institute of the Russian Academy of Sciences (Saint Petersburg, Russia).

\section{Results}

From the 253 passerines sampled (Table 1), feather mites were not found on the primary and tail feathers of 14 birds, namely, on one individual of Fringilla coelebs moreletti (Pucheran, 1859) from Graciosa, and on two individuals of Passer domesticus (Linnaeus, 1758) and 11 Pyrrhula murina from São Miguel. The other 239 (94\%) individuals sampled hosted one, two or three different feather mite species. In total, 19 feather mite species representing five genera and four families (Analgidae, Psoroptoididae, Proctophyllodidae and Trouessartiidae) were identified (Table 2). The prevalence of recorded feather mite species was high, reaching $100 \%$ in some species. With the exception of Analges passerinus, which was recorded on three different passerine hosts, all the other determined feather mite species were found on only one host. The recorded feather mite species, their host(s) and their prevalence on each host species are shown in Table 2. All feather mite species found constitute the first such records for the Azores.

\section{Discussion}

The present study of feather mites on passerines of the Azores is the first step towards identifying the feather mite communities on the Azores avifauna and understanding their origin, phylogeographic distribution and host-parasite relationships with avian hosts.

All feather mite species recorded in the course of this study belong to the four most abundant families of these mites occurring on passerines. Among them, mites of the families Proctophyllodidae and Trouessartiidae are predominantly associated with passerines, while representatives of the families Analgidae and Psoroptoididae are associated with a wide spectrum of bird orders and only some of their genera are restricted to passerines [16, 36]. Mites of the family Proctophyllodidae 
Table 1. Passerine species examined per island.

\begin{tabular}{|c|c|c|c|c|c|}
\hline \multirow[t]{2}{*}{ Bird species } & \multirow[t]{2}{*}{ Family } & \multicolumn{3}{|c|}{ Number of examined birds } & \multirow[t]{2}{*}{ Total } \\
\hline & & São Miguel & Santa Maria & Graciosa & \\
\hline Carduelis carduelis parva (Tschusi, 1901) & Fringillidae & 2 & 0 & 0 & 2 \\
\hline Erithacus rubecula (Linnaeus, 1758) & Muscicapidae & 9 & 6 & 3 & 18 \\
\hline Fringilla coelebs moreletti (Pucheran, 1859) & Fringillidae & 26 & 14 & 62 & 102 \\
\hline Motacilla cinerea patriciae (Vaurie, 1957) & Motacillidae & 1 & 0 & 0 & 1 \\
\hline Passer domesticus (Linnaeus, 1758) & Passeridae & 2 & 0 & 1 & 3 \\
\hline Pyrrhula murina (Godman, 1866) & Fringillidae & 18 & $*$ & $*$ & 18 \\
\hline Regulus regulus azoricus (Seebohm, 1883) & Regulidae & 6 & $*$ & $*$ & 6 \\
\hline Regulus regulus sanctaemariae (Vaurie, 1954) & Regulidae & $*$ & 10 & $*$ & 10 \\
\hline Serinus canaria (Linnaeus, 1758) & Fringillidae & 19 & 10 & 0 & 29 \\
\hline Sylvia atricapilla gularis (Alexander, 1898) & Sylviidae & 11 & 23 & 5 & 39 \\
\hline Turdus merula azorensis (Hartert, 1905) & Turdidae & 11 & 12 & 2 & 25 \\
\hline Total & & 105 & 75 & 73 & 253 \\
\hline
\end{tabular}

* Species do not breed on this island.

are the most typical inhabitants of the ventral side of wing and tail feathers; the Trouessartiidae are usually located on the dorsal side of wing and tail feathers; the Analgidae are most typically inhabitants of the downy feathers of the body; and the Psoroptoididae can inhabit the downy feathers, the greater coverts of the wings and even basal areas of primaries and tail feathers [7, 25].

Regarding the content of parasite assemblages of Azorean passerine hosts, only three species examined in this study Sylvia atricapilla, Regulus regulus (Linnaeus, 1758) and Serinus canaria (Linnaeus, 1758) - presented the same and apparently full complex of mite species commonly occurring in the plumage of these hosts or their closest relatives on mainland Europe [1, 4, 19, 24, 26, 27, 43]. These feather mite species complexes had been expected to occur inasmuch as these hosts colonized the Azores quite recently, i.e. within the last 0.7 million years $[8,9,41]$. It is also possible to surmise that the colonizing populations of these birds had borne the full set of feather mites and during the time since colonization of the Azores none of the mite species has become extinct.

Sylvia atricapilla commonly bears three species. Among these, Proctophyllodes sylviae is a monoxenous inhabitant of this host, Analges spiniger also occurs on other species of the genus Sylvia Scopoli, 1769 and Trouessartia bifurcata is known on Sylvia and Acrocephalus Naumann and Naumann, $1811[1,24,43]$.

Each of the two subspecies of Regulus regulus (from São Miguel and Santa Maria) sampled during this study bore two species of feather mites that are specific to goldcrests of the genus Regulus Cuvier, 1800 [1, 26, 27].

The wild form of Serinus canaria is endemic to Macaronesia (Azores, Madeira and Canary Islands). Three mite species recorded on this host are the same as those known from the closely related species Serinus serinus (Linnaeus, 1766), which is distributed in continental Europe [26]. Among these species, Proctophyllodes serini is specific to the genus Serinus Koch, 1816, while Analges passerinus is widely distributed on European species of the family Fringillidae [19, 24, 26]. A Mesalgoides species found on $S$. canaria and on S. serinus in the mainland of Europe (Mironov, unpublished data) is supposed to be a species new to science.

It should be mentioned that only exceptionally domestic canaries $(S$. canaria domestica) have been examined for the presence of feather mites [10, 46]. Schmäschke et al. [46] examined seven captive domestic canaries and found Proctophyllodes serinii, Analges passerinus and Strelkoviacarus sp. (Analgidae) on four, one and one birds, respectively. The finding of Strelkoviacarus sp. on domesticated canaries may be the result of transfer of this mite from wild passerines, because mites of the genus Strelkoviacarus (and likely many feather mite species of the family Epidermoptidae) are not typical feather mite species, in that they live on the skin and are able to disperse between different bird species by means of phoresy on hippoboscid flies of the genera Ornithomyia Latreille, 1802, Lynchia Williston, 1890 and many others specialized to birds (Diptera: Hippoboscidae) [18]; additionally, this mite was never found on wild canaries.

Carduelis carduelis parva (Tschusi, 1901) was introduced to the Azores during the 18th century [39]. The goldfinch was represented in our samples by only a single individual and displayed the same complex of species occurring on this host on the European mainland [19, 24, 26, 27]. Proctophyllodes pinnatus also occurs on some nearest species of the genus Carduelis, while A. passerinus is widely distributed on Eurasian passerines of the family Fringillidae. It should be noted, however, that $C$. carduelis has also been reported parasitized by a monoxenous species Mesalgoides travei Shereef and Rakha, 1981 in Egypt [47]. Since, despite frequent examination of C. carduelis for feather mites, the latter mite species has never been recorded elsewhere than in Egypt, we hypothesize that all European populations of $C$. carduelis, including the Azorean representatives, lack this species.

Erithacus rubecula (Linnaeus, 1758), also a recent colonizer of the archipelago [40], bears only two of the three common species that occur on this host in mainland Europe - P. rubeculinus and T. rubecula; both are specific inhabitants of this passerine [1, 43]. Analges unidentatus (Berlese, 1886), the third species known from E. rubecula, is distributed on 
Table 2. Host species and prevalence of identified avian feather mites.

\begin{tabular}{|c|c|c|c|c|c|}
\hline \multirow[t]{2}{*}{ Bird species } & \multirow[t]{2}{*}{ Feather mite species } & \multirow[t]{2}{*}{ Family } & \multicolumn{3}{|c|}{$\begin{array}{c}\text { Number of parasitized birds; } \\
\text { prevalence }(\%)^{*}\end{array}$} \\
\hline & & & São Miguel & Santa Maria & Graciosa \\
\hline \multirow[t]{2}{*}{ Carduelis carduelis } & Analges passerinus (Linnaeus, 1758) & Analgidae & 1 & - & - \\
\hline & Proctophyllodes pinnatus (Nitzsch, 1818) & Proctophyllodidae & 1 & - & - \\
\hline \multirow[t]{2}{*}{ Erithacus rubecula } & Trouessartia rubecula Jablonska, 1968 & Trouessartiidae & $9 ; 100 \%$ & $6 ; 100 \%$ & 2 \\
\hline & Proctophyllodes rubeculinus & Proctophyllodidae & $1 ; 11.1 \%$ & $1 ; 16.7 \%$ & 2 \\
\hline \multirow[t]{2}{*}{ Fringilla coelebs } & Monojoubertia microphylla Robin, 1877 & Proctophyllodidae & $25 ; 96.2 \%$ & $14 ; 100 \%$ & $61 ; 98.4 \%$ \\
\hline & Analges passerinus (Linnaeus, 1758) & Analgidae & $1 ; 3.9 \%$ & $0 ; 0 \%$ & $3 ; 4.8 \%$ \\
\hline Motacilla cinera patriciae & Trouessartia jedliczkai (Zimmermann, 1894) & Trouessartiidae & 1 & - & - \\
\hline Passer domesticus & Proctophyllodes troncatus Robin, 1877 & Proctophyllodidae & 0 & - & 1 \\
\hline \multirow[t]{2}{*}{ Pyrrhula murina } & Mesalgoides pyrrhulinus Mironov, 1997 & Psoroptoididae & $6 ; 33.3 \%$ & - & - \\
\hline & Analges macropus Zimmermann, 1894 & Analgidae & $6 ; 33.3 \%$ & - & - \\
\hline \multirow[t]{2}{*}{ Regulus regulus azoricus } & Trouessartia reguli Mironov, 1983 & Trouessartiidae & $6 ; 100 \%$ & - & - \\
\hline & Proctophyllodes reguli Gaud, 1957 & Proctophyllodidae & $1 ; 16.7 \%$ & - & - \\
\hline \multirow[t]{2}{*}{ Regulus regulus sanctaemariae } & Trouessartia reguli Mironov, 1983 & Trouessartiidae & - & $10 ; 100 \%$ & - \\
\hline & Proctophyllodes reguli Gaud, 1957 & Proctophyllodidae & - & $9 ; 90 \%$ & - \\
\hline \multirow[t]{3}{*}{ Serinus canaria } & Proctophyllodes serini Atyeo \& Braasch, 1966 & Proctophyllodidae & $17 ; 89.5 \%$ & $10 ; 100 \%$ & - \\
\hline & Analges passerinus (Linnaeus, 1758) & Analgidae & $12 ; 63.2 \%$ & $1 ; 10 \%$ & - \\
\hline & Mesalgoides sp. & Psoroptoididae & $1 ; 5.3 \%$ & $3 ; 30 \%$ & - \\
\hline \multirow[t]{3}{*}{ Sylvia atricapilla gularis } & Trouessartia bifurcata (Trouessat, 1884) & Trouessartiidae & $10 ; 90.9 \%$ & $19 ; 82.6 \%$ & $3 ; 60 \%$ \\
\hline & Analges spiniger Giebel, 1841 & Analgidae & $3 ; 27.3 \%$ & $0 ; 0 \%$ & $0 ; 0 \%$ \\
\hline & Proctophyllodes sylviae Gaud, 1957 & Proctophyllodidae & $2 ; 18.2 \%$ & $12 ; 52.2 \%$ & $3 ; 60 \%$ \\
\hline \multirow[t]{3}{*}{ Turdus merula azorensis } & Analges turdinus Mironov, 1985 & Analgidae & $1 ; 9.1 \%$ & $0 ; 0 \%$ & 0 \\
\hline & Proctophyllodes weigoldi Vitzthum, 1922 & Proctophyllodidae & $8 ; 72.7 \%$ & $4 ; 33.3 \%$ & 1 \\
\hline & Trouessartia incisa Gaud, 1957 & Trouessartiidae & $9 ; 81.8 \%$ & $9 ; 75 \%$ & 2 \\
\hline
\end{tabular}

* Calculated only when at least five birds of a given species were examined on the given island.

muscicapids of the genera Muscicapa Brisson, 1760, Ficedula Brisson, 1760, Phoenicurus Forster, 1817 and Erithacus Cuvier, 1800 and it has been recorded only in north-western Russia [26].

Turdus merula azorensis (Hartert, 1905) presented three of the five species known from the plumage of this species on continental Europe. P. weigoldi and A. turdinus are common species occurring on several other Turdus species in the Old World [1, 26], while Trouessartia incisa is known only from T. merula in Europe and Morocco $[14,43]$. The two other species, P. musicus Vitzthum, 1922 and Montesauria merulae Gaud, 1957, known also to be associated with various species of the genus Turdus [1, 14], are probably not present in the population of T. merula in the Azores.

Pyrrhula murina, endemic from São Miguel Island, displayed two feather mite species, Mesalgoides pyrrhulinus and Analges macropus, previously known to be specific to Pyrrhula pyrrhula [15, 24, 26, 27]. Quite surprising is the absence in this bird of Proctophyllodes simillimus Cerný, 1971, which is common to the closely related species P. pyrrhula $[6,26,27]$.

Fringilla coelebs moreletti displayed two of the three species occurring on the mainland populations of this host in Europe. Monojoubertia microphylla is a monoxenous inhabitant of this host, while $A$. passerines is associated with various Eurasian fringillids of the genera Fringilla, Carduelis, Acanthis and Spinus [2, 4, 19, 26, 27]. Pteronyssoides striatus (Robin, 1877) (Pteronyssidae), a monoxenous inhabitant of the
European $F$. coelebs [25, 27], presumably is not present on this host in the Azores.

These three hosts, Turdus merula, Pyrrhula murina and Fringilla coelebs, are the oldest passerine species to have colonized the archipelago, doing so more than 1 million years ago $[38,42,51]$. One possible explanation for the absence of some common feather mites on these passerines in the Azores could be the founder effect inherent to the colonization processes of isolated islands, called "missing the boat" by Macleod et al. [22], in which colonizing hosts may reach the islands carrying only a subset of their respective native feather mites assemblages [20, 32, 44]. On the other hand, it is also possible that the aforementioned mite species simply became extinct just after colonization of the Azores, phenomena called "drowning upon arrival" [22], due to some unfavourable environmental conditions, such as climate factors, which are known to influence the prevalence of feather mites on hosts [23]. As indicated above, such relatively new invaders to the Azores as Sylvia atricapilla, Regulus regulus have completely retained their native continental fauna.

The only individual of Motacilla cinerea patriciae (Vaurie, 1957) sampled during this work presented only one feather mite species, Trouessartia jedliczkai. This is a relatively common species from M. alba (Linnaeus, 1758) and M. flava (Linnaeus, 1758) [5, 17, 26, 43], but it has never been recorded before on $M$. cinerea. More samples are required in order to elucidate whether M. cinerea in the Azores bears feather mite species of the families Proctophyllodidae, Trouessartiidae and Analgidae as Motacilla spp. in continental Europe. 
Passer domesticus, introduced to the Azores in 1960 [39], has a quite limited fauna of feather mites living in its plumage even in Europe, in almost all studies consisting of the single species Proctophyllodes troncatus [3, 4, 17, 19, 26, 27]. This species is also common in Europe on other species of the genus Passer. Although only a single $P$. domesticus individual occurs in our samples, it is possible to state that its population, at least on Graciosa Island, has retained the original feather mite fauna from the mainland.

Thus, our study has shown that a number of passerine birds which colonized the Azores lack some of the feather mites occurring in the corresponding complexes of their populations or those of closely related species in continental Europe, which could have been caused by incomplete feather mite fauna carried by the individuals that colonized the Azores (i.e. the founder effect), or this could be due to the extinction of some mite species caused by some climatic conditions in this colonized territory.

The high prevalence of feather mite species recorded on the majority of hosts in this study could be due to the fact that all the passerine species sampled are sedentary and do not migrate [39]; which could also be the reason for the presence of lower species richness compared to the European mainland, since it is known that migratory birds are exposed to a wider assortment of mites than are non-migratory birds such as the Azorean species $[31,50]$. Another possible explanation for the high prevalences of feather mites on the majority of the hosts could lie in the fact that some of these species regularly form flocks during winter, and it is known that flocking species have higher mite prevalences than do solitary species [35]. Feather mites tend to be transmitted between individuals of the same group (flock) as well as from parents to offspring [33].

Acknowledgements. The authors would like to thank the Direcção Regional do Ambiente dos Açores for permission to capture birds in the Azores (Permission 69/2013/DRA). We acknowledge the Instituto da Conservação da Natureza e das Florestas for issuing ringing permits (186/2013 and 188/2014). We are also grateful to Joana Micael and Nelson Moura for their help with the fieldwork. All experiments complied with the current laws of Portugal, and the authors declare that they have no conflict of interest. Support to SM for the study was provided by a grant from the Russian Science Foundation (RSCF No. 14-14-00621).

\section{References}

1. Atyeo WT, Braasch NL. 1966. The feather mite genus Proctophyllodes (Sarcoptiformes: Proctophyllodidae). Bulletin of the University of Nebraska State Museum, 5, 1-354.

2. Atyeo WT, Gaud J. 1970. The feather mite genus Monojourbertia Radford, 1950 (Analgoidea: Proctophyllodidae). Entomologische Mitteilungen aus dem Zoologischen Staatsinstitut und Zoologischen Museum, Hamburg, 4, 145-155.

3. Behnke JM, McGregor PK, Shepherd M, Wiles R, Barnard C, Gilbert FS, Hurst JL. 1995. Identity, prevalence and intensity of infestation with wing feather mites on birds (Passeriformes) from the Setubal Peninsula of Portugal. Experimental and Applied Acarology, 19, 443-458.
4. Burdejnaja SYa, Kivganov DA. 2009. Taxonomic characteristic of mites of the family Proctophyllodidae from birds migrating via Zmeiny Island. Zapovidna Sprava v Ukraini, 15, 71-75.

5. Burdejnaja SYa, Kivganov DA. 2009. Feather mites of the genus Trouessartia Canestrini, 1899 (Acari: Trouessartiidae) passerine birds of Ukraine. Visnyk Odes'kogo Nacional'nogo Universytetu, 14, 75-80.

6. Černý V. 1971. Zur Kenntnis der Federmilben (Arch., Acar.) von schweizerischen Vögeln. Mitteilungen der Schweizerischen entomologischen Gesellschaft, 44, 285-298.

7. Dabert J, Mironov SV. 1999. Origin and evolution of feather mites (Astigmata). Experimental and Applied Acarology, 23, 437-454.

8. Dietzen C, Voigt C, Wink M, Gahr M, Leitner S. 2006. Phylogeography of island canary (Serinus canaria) populations. Journal of Ornithology, 147, 485-494.

9. Dietzen C, Garcia-Del-Rey E, Castro GD, Wink M. 2008. Phylogenetic differentiation of Sylvia species (Aves: Passeriformes) of the Atlantic islands (Macaronesia) based on mitochondrial DNA sequence data and morphometrics. Biological Journal of the Linnean Society, 95, 157-174.

10. Dorrestein GM, Van der Horst HHA, Cremers HJWM, Van der Hage M. 1997. Quill mite (Dermoglyphus passerinus) infestation of canaries (Serinus canaria): Diagnosis and treatment. Avian Pathology, 26, 195-199.

11. Drake JM. 2003. The paradox of the parasites: implications for biological invasion. Proceedings of the Royal Society of London B, 270, S133-S135.

12. Evans GO. 1992. Principles of acarology. CAB International, Wallingford, UK.

13. França Z, Cruz JV, Nunes JC, Forjaz VH. 2003. Geologia dos Açores: uma perspectiva actual. Açoreana, 10, 11-140.

14. Gaud J. 1957. Acariens plumicoles (Analgesoidea) parasites des oiseaux du Maroc. I. Proctophyllodidae. Bulletin de la Société de Sciences naturelles et physiques du Maroc, 37, 105-136.

15. Gaud J. 1974. Quelques espèces nouvelles de sarcoptiformes plumicoles (Analgidae et Dermoglyphidae) parasites d'oiseaux d'Europe. Acarologia, 15, 727-758.

16. Gaud J, Atyeo WT. 1996. Feather mites of the world (Acarina, Astigmata): the supraspecific taxa. Tervuren, Belgium: Musée Royal de l'Afrique Centrale, 277, 1-193 (Pt. 1, text), 1-436 (Pt. 2, illustrations).

17. Gürler AT, Mironov SV, Erciyes-Yavuz K. 2013. Avian feather mites (Acari: Astigmata) of Samsun, Turkey. Acarologia, 53, $17-23$.

18. Hill DS, Wilson N, Corbet GB. 1967. Mites associated with British species of Ornythomyia (Diptera: Hippoboscidae). Journal of Medical Entomology, 4, 102-122.

19. Kolarova NT, Mitov PG. 2008. Feather mites of the superfamily Analgoidea (Acari: Astigmata) from passerines (Aves: Passeriformes) in South Dobrudzha, Bulgaria. Acta Zoologica Bulgarica, Suppl. 2, 91-102.

20. Lafferty KD, Torchin ME, Kuris AM. 2010. The geography of host and parasite invasions, in The biogeography of hostparasite interactions. Morand S, Krasnov BR, Editors. Oxford University Press: New York. p. 191-203.

21. Literak I, Sychra O, Resendes R, Rodrigues P. 2014. Chewing lice in Azorean blackcaps Sylvia atricapilla: a contribution to parasite island syndromes. Journal of Parasitology, in press, DOI: $10.1645 / 14-601.1$ 
22. MacLeod CJ, Paterson AM, Tompkins DM, Duncan RP. 2010. Parasites lost - Do invaders miss the boat or drown on arrival? Ecology Letters, 13, 516-527.

23. Meléndez L, Laiolo P, Mironov S, García M, Magaña O, Jovani R. 2014. Climate-driven variation in the intensity of a host-symbiont animal interaction along a broad elevation gradient. PLoS ONE, 9(7), e101942, DOI: 10.1371/journal.pone.0101942.

24. Mironov SV. 1985. Feather mites of the genera Analges and Pteronyssoides from the European part of the USSR (Sarcoptiformes, Analgoidea). Parazitologicheskii Sbornik, 33, 159-208.

25. Mironov SV. 1987. Morphological adaptations of feather mites to different types of plumage and skin of birds. Parazitologicheskii Sbornik, 34, 114-132.

26. Mironov SV. 1996. Feather mites of the passerines of the NorthWest of Russia. Parazitologiya, 30, 521-539.

27. Mironov SV. 1997. Contribution to the feather mites of Switzerland with descriptions of five new species (Acarina: Sarcoptiformes). Bulletin de la Société Entomologique Suisse, 40, 455-471.

28. Mironov SV. 2003. On some problems in the systematics of feather mites. Acarina, 11, 3-29.

29. Mironov SV, Proctor HC. 2008. The probable association of feather mites of the genus Ingrassia (Analgoidea: Xolalgidae) with the blue penguin Eudyptula minor (Aves: Sphenisciformes) in Australia. Journal of Parasitology, 94, 1243-1248.

30. Mironov SV, Literak I, Nguyen MH, Capek M. 2012. New feather mites of the subfamily Pterodectinae (Acari: Proctophyllodidae) from passerines and woodpeckers (Aves: Passeriformes and Piciformes) in Vietnam. Zootaxa, 3440, $1-19$.

31. Møller AP, Erritzøe J. 1998. Host immune defence and migration in birds. Evolutionary Ecology, 12, 945-953.

32. Nieberding C, Morand S, Libois R, Michaux JR. 2006. Parasites and the island syndrome: the colonization of the western Mediterranean islands by Heligmosomoides polygyrus (Dujardin, 1845). Journal of Biogeography, 33, $1212-1222$

33. O'Connor BM. 1994. Life-history modifications in astigmatid mites, in Mites: Ecological and evolutionary analyses of lifehistory patterns. Houck MA, Editor. Chapman \& Hall: London. p. $136-159$.

34. O'Connor BM. 2009. Astigmatina, in A manual of acarology, 3rd edn. Krantz GW, Walter DE, Editors. Texas Tech University Press: Lubbock. p. 565-657.

35. Poulin R. 1991. Group-living and infestation by ectoparasites in passerines. Condor, 93, 418-423.

36. Proctor HC. 2003. Feather mites (Acari: Astigmata): ecology, behavior and evolution. Annual Review of Entomology, 48, 185-209.

37. Proctor HC, Owens I. 2000. Mites and birds: diversity, parasitism and coevolution. Trends in Ecology \& Evolution, $15,358-364$.
38. Rodrigues P. 2012. Phylogeography and genetic diversity of the Azores passerines. PhD thesis. Universidade dos Açores: Ponta Delgada. p. 186

39. Rodrigues P, Cunha R. 2010. Azorean birds - a natural heritage. Açoreana, Suppl. 7, 319-330.

40. Rodrigues P, Lopes RJ, Drovetski SV, Reis S, Ramos JA, Cunha RT. 2013. Phylogeography and genetic diversity of the Robin (Erithacus rubecula) in the Azores islands: evidence of a recent colonisation. Journal of Ornithology, 154, 889-900.

41. Rodrigues P, Lopes RJ, Micael J, Resendes R, Ramos JA, Cunha RT. 2014. Genetic and morphometric diversity of the goldcrest (Regulus regulus) populations in the Azores. Zoology, 117, 383-391.

42. Rodrigues P, Lopes RJ, Reis S, Resendes R, Ramos JA, Cunha RT. 2014. Genetic diversity and morphological variation of the common chaffinch Fringilla coelebs in the Azores. Journal of Avian Biology, 45, 167-178.

43. Santana FJ. 1976. A review of the genus Trouessartia (Analgoidea: Alloptidae). Journal of Medical Entomology, Suppl. 1, 1-128.

44. Sari EHR, Klompen H, Parker PG. 2012. Tracking the origins of lice, haemosporidian parasites and feather mites of the Galápagos flycatcher (Myiarchus magnirostris). Journal of Biogeography, 40, 1082-1093.

45. Schatz H, Behan-Pelletier VM, O'Connor BM, Norton RA. 2011. Suborder Oribatida van der Hammen, 1968. In: Z.-Q. Zhang (Ed.) Animal biodiversity: An outline of higher-level classification and survey of taxonomic richness. Zootaxa, 3148, 141-148.

46. Schmäschke R, Sachse M, Schöne R. 2004. Federmilben wenig bekannte Ektoparasiten bei Vögeln? Abhandlungen und Berichte des Naturkundemuseum Görlitz, 76, 57-69.

47. Shereef GM, Rakha MA. 1981. Four new species of feather mites in Egypt (Acaridida: Analgidae). Bulletin of the Zoological Society of Egypt, 31, 77-86.

48. Stefan LM, Gómez-Díaz E, Mironov SV. 2013. Three new species of the feather mite subfamily Ingrassiinae (Acariformes: Xolalgidae) from shearwaters and petrels (Procellariiformes: Procellariidae). Zootaxa, 3682, 105-120.

49. Stefan LM, McCoy KD, Mironov SV. 2014. A new species of the feather mite genus Rhinozachvatkinia (Acari: Avenzoariidae) from Calonectris shearwaters (Procellariiformes: Procellariidae): integrating morphological descriptions with DNA barcode data. Folia Parasitologica, 61, 90-96.

50. Sychra O, Literák I, Podzemny P, Harmat P, Hrabák R. 2011. Insect ectoparasites on wild birds in Czech Republic during the pre-breeding period. Parasite, 18, 13-19.

51. Töpfer T, Haring E, Birkhead TR, Lopes RJ, Severinghaus LL, Martens J, Päckert M. 2011. A molecular phylogeny of bullfinches Pyrrhula Brisson, 1760 (Aves: Fringillidae). Molecular Phylogenetics and Evolution, 58, 271-282.

52. Torchin ME, Lafferty KD, Dobson AP, McKenzie VJ, Kuris AM. 2003. Introduced species and their missing parasites. Nature, 421, 628-630. 
Cite this article as: Rodrigues P, Mironov S, Sychra O, Resendes R \& Literak I: Feather mites (Acari, Astigmata) from Azorean passerines (Aves, Passeriformes): lower species richness compared to European mainland. Parasite, 2015, 22, 8.

\section{- PARASTE}

An international open-access, peer-reviewed, online journal publishing high quality papers on all aspects of human and animal parasitology

Reviews, articles and short notes may be submitted. Fields include, but are not limited to: general, medical and veterinary parasitology; morphology, including ultrastructure; parasite systematics, including entomology, acarology, helminthology and protistology, and molecular analyses; molecular biology and biochemistry; immunology of parasitic diseases; host-parasite relationships; ecology and life history of parasites; epidemiology; therapeutics; new diagnostic tools.

All papers in Parasite are published in English. Manuscripts should have a broad interest and must not have been published or submitted elsewhere. No limit is imposed on the length of manuscripts.

Parasite (open-access) continues Parasite (print and online editions, 1994-2012) and Annales de Parasitologie Humaine et Comparée (1923-1993) and is the official journal of the Société Française de Parasitologie. 